\title{
Studies on Estrus Induction in Ewes during Non-Breeding Season
}

\author{
Jaan Mohammad Wani ${ }^{1}$, Utsav Sharma ${ }^{1}$, Sajad A. Beig ${ }^{2}$, Suhaib ul Haq Khan ${ }^{3}$, \\ Moien Javaid ${ }^{*}$, Mudasir Bashir ${ }^{4}$, A.K. Pandey ${ }^{1}$, Umer Ali ${ }^{5}$ and Rouf Rashid Dar ${ }^{6}$ \\ ${ }^{1}$ Division of Veterinary Gynaecology and Obstetrics, F. V. Sc \& A. H, SKUAST- Jammu, J \& K, India \\ ${ }^{2}$ Division of Animal Biotechnology, F. V. Sc \& A. H, SKUAST- Kashmir, J \& K, India \\ ${ }^{3}$ Division of Veterinary Microbiology, G. B. Pant University of Agriculture and Technology, \\ Uttrakhand, India \\ ${ }^{4}$ Division of Veterinary Public Health and Epidemiology, F. V. Sc \& A. H, SKUAST- Kashmir, \\ $\mathrm{J} \& \mathrm{~K}$, India \\ ${ }^{5}$ Division of Veterinary Public Health, F. V. Sc \& A. H, SKUAST- Kashmir, J \& K, India \\ ${ }^{6}$ Division of Veterinary Gynaecology and Obstetrics, Indian Veterinary Research Institute, Bareilly, India \\ *Corresponding author
}

\begin{tabular}{|c|c|}
\hline & A B S T R A C T \\
\hline & \multirow{6}{*}{ 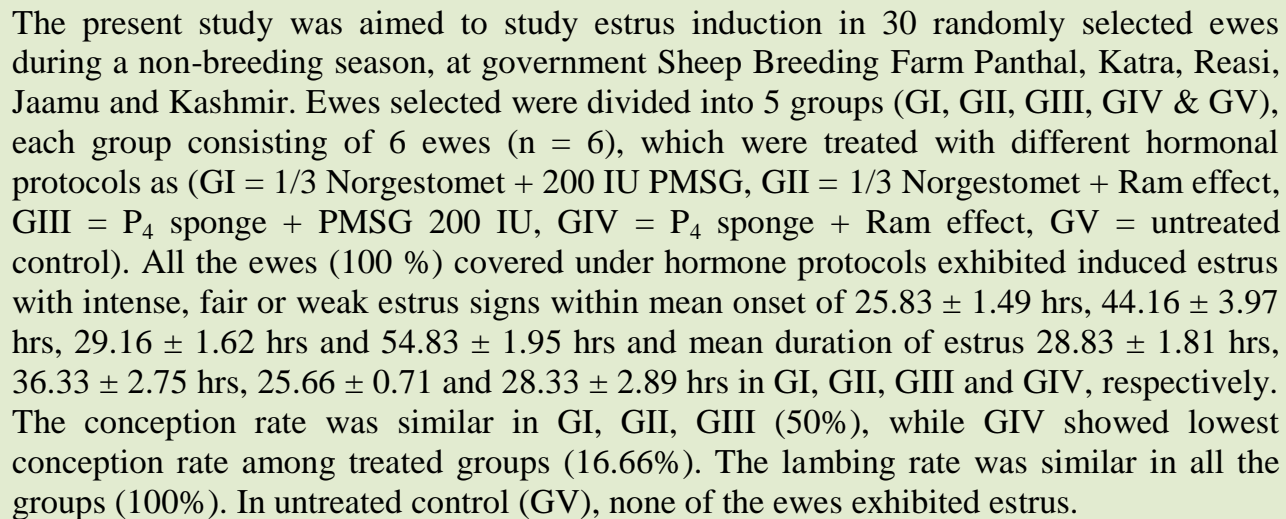 } \\
\hline Reywords & \\
\hline $\begin{array}{l}\text { Ewe, Estrus } \\
\text { induction, P4 }\end{array}$ & \\
\hline $\begin{array}{l}\text { Sponge, PMSG, } \\
\text { Ram effect. }\end{array}$ & \\
\hline Article Info & \\
\hline $\begin{array}{l}\text { Accepted: } \\
\text { 10 October } 2017 \\
\text { Available Online: } \\
10 \text { December } 2017\end{array}$ & \\
\hline
\end{tabular}

\section{Introduction}

The control of estrus and ovulation in sheep with progesterone and its analogues has been extensively evaluated, applied and accepted in sheep breeding programmes (Robinson, 1967; van Niekerk and Belonje, 1970; Boshoff et al., 1973; Haresign, 1978; Hunter, 1980). Reproductive seasonality in ewes is characterized by changes in behavioral, endocrine, and ovulatory patterns (Epstein, 1985; Rosa and Bryant, 2003). The majority of sheep breeds are anestrus for at least some proportion of the year (Rekwot et al., 2001) with the degree and depth of seasonality dependent upon breed and climate. In Jammu and Kashmir non breeding season of sheep falls mostly between April and September. The methods for induction of estrus out of season breeding in ewes have revolved around the use of $\mathrm{P}_{4}$ pessaries and PMSG (Mcleod and Haresign, 1984). Progestagens are administered as daily injections, orally, intra vaginal devices like CIDR, PRID and 
subcutaneous ear implants like Crestar. Progestagens or its analogues along with gonadotrophin have been extensively used to induce estrus in anestrus ewes, although pregnancy rates of progestagen-synchronized ewes are lower during anestrus than during the breeding season. Intravaginal sponges are usually inserted over periods of 6-14 days and an injection of PMSG is administered prior or at time of sponge removal (Wildeus, 2000 and Ustuner et al., 2007). Many studies have incorporated the use of norgestomet implants for out of season breeding with pregnant mare serum gonadotropin (PMSG) (Fitch et al., 1986 and Yelich et al., 1992). Ram effect is also used to achieve breeding activity during the non-breeding season. Anestrus ewes are isolated from rams before the start of normal breeding season, introduction of rams to ewes induces ovulation, and this method is referred to as the ram effect or male effect (Jordan, 2005). The ram effect allows induction of breeding during anestrus and produces some synchrony in the cycle among the ewes in flock (Chanvallon et al., 2008). The aim of this study was to evaluate the effect of crestar and intra vaginal progesterone sponge in combination with ram effect or Equine Chorionic Gonadotropin (eCG) on the reproductive efficiency of ewes during nonbreeding season.

\section{Materials and Methods}

The present study was conducted on 30 ewes during non-breeding season at government Sheep Breeding Farm, Panthal, Katra, District Reasi, Jammu (J\&K). The average temperature and relative humidity during the period of study were $33^{\circ} \mathrm{C}$ and $58.5 \%$ respectively. The period extended from May to August, 2015. Age, Body weight and Body condition score were recorded in all animals. Ewes were randomly divided into 5 groups consisting of 6 animals in each group. In group I, ewes $(n=6)$ were treated with
Crestar ear implants @ 1mg Norgestomet (1/3 of the $3 \mathrm{mg}$ implant used in large animals) on day 0 (Fig. 1b). The implant was removed on day 12 and an injection of PMSG (200 IU) was given on the day of implant removal. In group II, ewes $(n=6)$ were treated with Crestar ear implants @1mg Norgestomet (1/3 of the $3 \mathrm{mg}$ implant used in large animals) on day 0 . The implant was removed on day 12 and a ram was introduced $72 \mathrm{hrs}$ before the implant removal. In group III, ewes $(n=6)$ were treated with conventional $\mathrm{P}_{4}$ sponge for 12 days (Fig. 1a). An injection of PMSG (200 IU) was given on the day of $\mathrm{P}_{4}$ sponge removal. In group IV, ewes $(n=6)$ were treated with conventional $\mathrm{P}_{4}$ sponge for 12 days. The sponge was removed on day 12 and a ram was introduced $72 \mathrm{hrs}$ before the sponge removal. In group $\mathrm{V}$, ewes $(n=6)$ were kept without any treatment and were sampled on the same days as in treatment groups.

\section{Results and Discussion}

The efficacy of all the protocols was studied regarding estrus induction response, onset of estrus, duration of estrus, estrus intensity, conception rate and lambing rate. The estrus intensity was described as intense fair and weak on the basis of signs of estrus. The data regarding all the parameters in all the five groups is shown in Table 1.

All the ewes (100.00\%) in Group I, II, III and IV responded to treatment and exhibited estrus, whereas, in Group V (Control), none of ewes exhibited estrus during the period of study. Our findings were in complete agreement with the work done by various workers in which estrus induction rate was $100 \%$ on treating with exogenous progestagen for a specific time period or using a combination of progestagen and gonadotropins (Juma, 2010; Das et al., 1999; Kashifalkita, 2003; Alwan, 2012; Kohno et al., 2005). Likewise, our results in PMSG 
treated ewes (Group I, Group III) are in close agreement with results of Boland et al., (1979), Carpenter et al., (1981), Alifakiotis (1985), Tritschler et al., (1991), Amer and Hazzaa (2009), Kor et al., (2012). Differing from our results, lower estrus induction rates ranging from $46 \%$ to $93 \%$ were reported by Redmer et al., (1998), Kusina et al., (2000), Mellado et al., (2000), Das et al., (2004), Ataman et al., (2006), Dogan and Nur (2006), Ali (2007), Abu Gazal (2010), Bogdan et al., (2011), Santos et al., (2011), Sarminejad et al., (2014).

Our results of Group II and IV (ram effect groups) are almost in close proximity with results of Mellado et al., (2000) who found an estrus induction rate of $92 \%$ when bucks were exposed to goats 2 days before the end of Synchromate-B (SMB) treatment. Chanvallon et al., (2008) also observed that ram effect allows induction of breeding during anestrus and produce some synchrony in the cycle among the ewes in flock. Unlike to our results, Ungerfeld et al., (2005) found induction rate of $71 \%$ when ram was introduced to ewes primed with MAP for 6 days during non-breeding season. Iida et al., (2004) found that ram presence resulted in higher ovulation rate than without rams but there was no significant $(\mathrm{p}<0.05)$ difference. Higher estrus induction rate in our study might be due to less seasonal breeding pattern of ewes, good body condition, good ram to ewe ratio, better management and feeding of ewes. Other factors like age, parity, breed of ewe, lambing to induction interval, breed and percentage of rams used, depth of anestrus, geographical location might have lead to variation in response.

Estrus onset was earlier in groups treated with PMSG (Group I and III). Our results are in complete agreement with earlier results of
Botha et al., (1975), Dogan and Nur (2006), Omontese et al., (2012), Cline et al., (2001), Redmer et al., (1998) and Gardon et al., (2015) who reported that time to estrus was shorter in eCG treated ewes than eCG untreated ewes.

In contradiction, higher estrus onset interval were also reported by Marco-Jimenez et al., (2014) (73.2 \pm 86.7 h), Abu Gazal (2010) $(60.7 \pm 20.3$ h), Ali (2007) (69 \pm 9.9 h). Estrus onset was delayed in groups exposed to ram prior to $\mathrm{P}_{4}$ withdrawal. Our results are in agreement with earlier reports of Ungerfeld $e t$ al., (2005) and Jarquin et al., (2014). Unlike to our study, a shorter estrus onset interval of 21 h was reported by Iida et al., (2004). Between the ram exposed groups, estrus onset was more delayed in Group IV. This might be due to failure in absorption of $\mathrm{P}_{4}$ from Intravaginal sponge, due to which there would have been some $\mathrm{P}_{4}$ residue which would have lead to prolonged negative feedback of $\mathrm{P}_{4}$ on cyclicity and hence delayed onset of estrus (residual effect). Besides it, ram effect might not be adequate to increase the LH pulse frequency. Similarly, Iida et al., (2004) reported that absorption of $\mathrm{P}_{4}$ is important for proper estrus behavior and ovulation. There might be also low circulating testosterone level in the ram used, which might have led to delay in LH surge, hence delayed estrus onset.

Similar results were earlier reported by Perkins and Fitzgerald (1994) who observed that factors affecting the circulating levels of testosterone will affect the quality and thus efficacy of the ram stimulus. Besides it, other factors like quality, type and duration of ram stimulus are critical to extent of ovulatory response to the ram effect (Walkden-Brown et al., 1999), which might have lead to delayed estrus onset in our study. 
Fig.1 (a) Conventional sponge protocol, (b) Crestar protocol

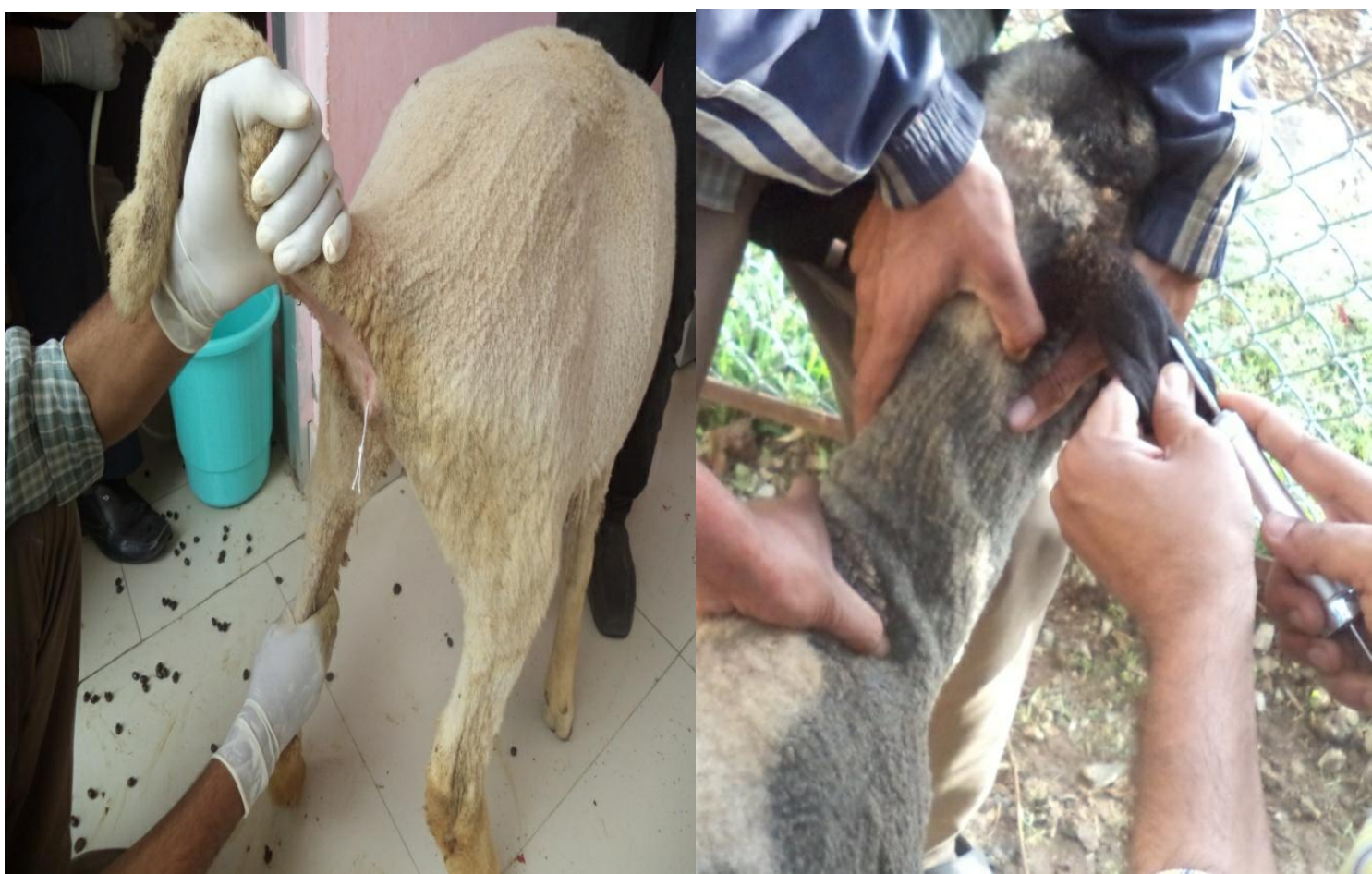

Table.1 Data regarding estrus induction response, onset of estrus, duration of estrus, conception rate and lambing rate in all the five groups

\begin{tabular}{|c|c|c|l|c|c|c|}
\hline $\begin{array}{c}\text { Treatment } \\
\text { Groups }\end{array}$ & $\begin{array}{c}\text { No. of } \\
\text { ewes } \\
\text { treated }\end{array}$ & $\begin{array}{c}\text { No. of animals } \\
\text { responded (\%) }\end{array}$ & $\begin{array}{l}\text { Estrus onset } \\
\text { (hr) (Mean } \pm \\
\text { SE) }\end{array}$ & $\begin{array}{c}\text { Estrus } \\
\text { Duration (hr) } \\
\text { (Mean } \pm \text { SE) }\end{array}$ & $\begin{array}{c}\text { Total } \\
\text { Conception } \\
\text { Rate }\end{array}$ & $\begin{array}{c}\text { Lambing } \\
\text { Rate }(\%)\end{array}$ \\
\hline Group I & 6 & $6(100)$ & $25.83 \pm 1.49^{\mathrm{a}}$ & $28.83 \pm 1.81^{\mathrm{a}}$ & $50.00 \%$ & $2 / 2(100.00 \%)$ \\
\hline Group II & 6 & $6(100)$ & $44.16 \pm 3.97^{\mathrm{b}}$ & $36.33 \pm 2.75^{\mathrm{b}}$ & $50.00 \%$ & $3 / 3(100.00 \%)$ \\
\hline Group III & 6 & $6(100)$ & $29.16 \pm 1.62^{\mathrm{a}}$ & $25.66 \pm 0.71^{\mathrm{a}}$ & $50.00 \%$ & $3 / 3(100.00 \%)$ \\
\hline Group IV & 6 & $6(100)$ & $54.83 \pm 1.95^{\mathrm{c}}$ & $28.33 \pm 2.89^{\mathrm{a}}$ & $16.66 \%$ & $1 / 1(100.00 \%)$ \\
\hline Group V & 6 & $0(0.00)$ & & & $0.00 \%$ & $0 / 6(0.00 \%)$ \\
\hline
\end{tabular}

Means bearing different superscripts down a column differ significantly $(\mathrm{P}<0.05)$

Table.2 Data regarding estrus induction response, onset of estrus, duration of estrus, conception rate and lambing rate in all the five groups

\begin{tabular}{|c|c|c|c|}
\hline \multirow{2}{*}{ Treatment Groups } & \multicolumn{3}{|c|}{ Intensity of Estrus } \\
\cline { 2 - 4 } & Intense & Fair & Weak \\
\hline Group I & $4(66.66 \%)$ & $1(16.66 \%)$ & $1(16.66 \%)$ \\
\hline Group II & $4(66.66 \%)$ & $2(33.33 \%)$ & $0(0.00 \%)$ \\
\hline Group III & $4(66.66 \%)$ & $2(33.33 \%)$ & $0(0.00 \%)$ \\
\hline Group IV & $3(50.00 \%)$ & $1(16.66 \%)$ & $2(33.33 \%)$ \\
\hline
\end{tabular}

Figures in parenthesis represent the percentage 
The duration of estrus was longest in Group II and differed significantly $(\mathrm{P}<0.05)$, compared to other groups which differed nonsignificantly $(\mathrm{P}>0.05)$. Estrus duration was less in Group I, III and IV ewes. In previous studies, and in accordance with current study, it was reported that mating decreased the duration of estrus (Romano, 1993). One service reduced the duration of estrus by $45 \%$, but the response was not affected (Romano, 1994a). Authors have suggested that penile intromission stimulates mechanisms involved in estrus shortening (penile effect) (Romano, 1994b). But in Group II of our study, ram was introduced close to onset of breeding season in ewes that might have lead to increased response of ewes, resulting in prolonged estrus duration. Likewise, Cushwa et al., (1992) and Oldham et al., (1984) also observed that ewes are more receptive to the ram stimulus when rams are introduced close to the spontaneous onset of the breeding season. In contradiction to our results, shorter estrus duration were reported by Sareminejad et al., (2014) (14.77 $\pm 1.33 \mathrm{~h})$, Abu Gazal (2010) $(12.1 \pm 7.3 \mathrm{~h}, 12.8 \pm 8.3 \mathrm{~h}$ and $13.7 \pm$ $11.3 \mathrm{~h}$ w.r.t. different dosage rates of $\mathrm{P}_{4}$ and PMSG), Ekiz et al., (2006) (18.0 \pm 2.86 h).

Intensity of estrus in Group I ewes was good in 4 ewes $(66.66 \%)$, fair in 1 ewe $(16.66 \%)$ and weak in 1 ewe $(16.66 \%)$. This is in accordance with the findings of Bhoraniya et al., (2012) who reported that cows treated with CIDR protocol, showed prominent $(66.66 \%)$, moderate $(16.66 \%)$ and weak $(16.66 \%)$ estrus signs. In Group II and III ewes, intensity of estrus was intense in 4 ewes $(66.66 \%)$, fair in 2 ewes $(33.33 \%)$ and weak in none of the ewes $(0.00 \%)$. This is in close concurrence with result values of Amle et al., (2012) who studied the effect of Ovsynch plus CIDR protocol in postpartum crossbred cows and found the intensity of estrus was $70 \%$ intense, $30 \%$ intermediate and $0 \%$ weak. In Group IV ewes, intensity of estrus was intense in 3 ewes (50\%), fair in 1 ewe $(16.66 \%)$ and weak in 2 ewes $(33.33 \%)$. This is in close concurrence with result values of Ungerfeld et al., (2005) who found that \% of ewes in estrus was $71 \%$ approximately, with $35.5 \%$ (approx.) ewes showing overt signs and $35.5 \%$ (approx.) showing silent estrus.

Conception rate was equal to $50 \%$ in Group I, II and III. Our results were in close concurrence with earlier results of Carpenter et al., (1981), Husein and Kridli (2002), Kohno et al., (2005), Amer and Hazzaa (2009), Garoussi et al., (2012), Sareminejad et al., (2014) who reported conception rates in the range of $50 \%$ to $55 \%$. Unlike to our study, higher conception rates ranging from $71.42 \%$ to $100 \%$ were reported by Das et al., (1999), Dogan and Nur (2006), Awel et al., (2009), Bogdan et al., (2011), Zonturlu et al., (2011), Taher (2014). Likewise lower conception rates rate of $10 \%$ was reported by Taher (2014) using FGA sponge; $44.3 \%$ by Yelich et al., (1992) using norgestomet+ PMSG-hCG combination; $44.4 \%$ by Dogan and Nur (2006) using MAP alone; $42.85 \%$ by Awel et al., (2009) using full dose of norgestomet implant + injectable + eCG; $40.7 \%$ by Kohno et al., (2005) using intravaginal $\mathrm{P}_{4}$ cream + eCG. Conception rate was lowest in Group IV, equal to $16.66 \%$. This low conception rate in current study might be due to poor estrus intensity of Group IV ewes (fair $=16.66 \%$ and weak $=33.33 \%$ ) and delayed estrus onset which might have lead to poor LH surge and ovulation, hence conception was lowest (Table 2).

Lambing rate was $100.00 \%$ in all the groups i.e., Group I, II, III, IV. In Group I ewes, only 2 ewes lambed and 1 ewe died before lambing out of the 3 conceived ewes and this dead one was excluded from the experiment, thus the total lambing rate was $2 / 2(100.00 \%)$. In Groups II, III \& IV ewes, all conceived ewes lambed (3/3 ewes in Group II \& III; 1/1 ewes 
in Group IV). None of ewes in treatment group showed twinning or triplet births. In Group V, none of the ewes were observed in estrus and conceived, therefore there was no lambing. In norgestomet groups (Group I and Group II), our results are in complete agreement with earlier results of Alifakiotis (1985) and Awel et al., (2009). In sponge groups (Group III and Group IV), our results are in complete agreement with earlier results of Zonturlu et al., (2011) and Taher (2014). On the other hand, a lower lambing rate of $62 \%, 39 \%, 71 \%, 28 \%$ were reported by Alifakiotis (1985).

\section{References}

Abu Gazal Baher Mahmoud Ode. 2010. Different estrous Induction Protocols during the non-breeding season in Assaf ewes. Thesis, 1-77.

Ali, A. 2007. Effect of time of eCG administration on follicular response and reproductive performance of FGA-treated Ossimi ewes. Small ruminant research, 72(1): 33-37.

Alifakiotis, T. 1985. Induced breeding in anestrous milking ewes of dairy breeds: Comparison of norgestomet, medroxyprogesterone and fluorogestone in Two Regimes of PMSG. Current topics in veterinary medicine and animal science, 31: 76-82.

Alwan, Ali. Fadel. 2012. Thyroid hormones concentrations in relation to hormonal estrous induction, laparoscopical insemination and pregnancy out of breeding seasons. International Journal of Animal and Veterinary Advances. 4(5): 333-337.

Amer, Hussein. Ahmed. and Hazzaa, Abubakr. Maher. 2009. The effect of different progesterone protocols on the reproductive efficiency of ewes during the non-breeding season. Veterinarski Arhiv, 79 (1): 19-30.

Amle, M. B., Nevkar, S. G., Birade, H. S., Gaikwad, S. M., Ulemale, A. H. and
Bavaskar, M. S. 2012. Effect of CIDR + Ovsynch estrus synchronization protocol on estrus response and fertility rate in crossbred cows. National Symposium on Addressing Animal Reproduction Stresses through Biotechnological Tool and XXVIII Annual Convention of The Indian Society for Study of Animal Reproduction and National Symposium held at Assam Agricultural University, Khanapara Guwahati-22, Assam. November 21-23. p. 114.

Ataman, M. B., M, Akoez., O, Akman. 2006. Induction of synchronized estrous in Akkaraman cross-bred ewes during breeding and anestrous seasons, the use of short-term and long-term progesterone treatments. Rev. Med. Vet, 5: 257-260.

Awel, Hayatu., Eshetu, Lisanework., Tadesse, Gebrehiwot., Birhanu, Alemselam., Khar, S. K.2009. Estrus synchronization in sheep with synthetic progestagens. Tropical Animal Health Production, 41: 1521 - 1524.

Bhoraniya, B. L., Dhami, A. J. and Killedar, A. 2012. Influence of Estrus Synchronization Protocols on Fertility Plasma Progestrone and Biochemical Constituents in Kankrej Cows. Indian Journal of Animal Reproduction, 33: 2.

Bogdan, Liviu., Groza, Ioan., Pop, Raul., Petrean, Anamaria., Bogdan, Sidonia. 2011. Induction and oestrus synchronization in sheep during breeding and non-breeding season. Bulletin UASVM, Veterinary Medicine, 68(2).

Boland, M. P., Kellher, D. and Gordon, I. 1979. Comparison of control of estrus andovulation in sheep by an ear implant (SC 21009) or by intravaginal sponge (cronolne or MAP). Animal Reproduction Science, 1: 275-281.

Boshoff, D.A., Van niekerk, E.H. and Morgenthal, J.E. 1973. Time of ovulation in the Karakul ewe following synchronization of oestrus. South African Journal of Animal Science, 3: 13.

Botha, H. K., Van Niekerk, C. H. and Pagel, R. F. E. 1975. The influence of 
synchronisation of estrus period, PMSG administration and flushing on: estrus conception of South African. South African Journal of Animal Science, 5: 231-233.

Carpenter, R. H., Spitzera, J. C. 1981. Response of anestrous ewes to norgestomet and PMSG. 15(4): 389-393.

Chanvallon, A., Blache, D., Chadwick, A., Esmaili, T., Hawken, P. A. R., Martin, G. B., Vinoles, C., Fabre-Nys. C. 2008. Sexual experience and temperament affect the response of Merino ewes to the ram effect during the anoestrous season. Animal Reproduction Science. Doi, 10: 1016.

Cline, M. A., Ralston, J. N., Seals, R. C. and Lewis, G. S. 2001. Intervals from norgestomet withdrawal and injection of equine chorionic gonadotropin or P.G. 600 to estrus and ovulation in ewes. Journal of Animal Science, 79: 589-594.

Cushwa, T.W., Bradford, G.E., Stabenfeldt, G.H., Berger, Y.M. and Dally, M.R. 1992. Raminfluence on ovarian and sexual activity in anestrous ewes: effects of isolation of ewes from rams before joining and date of ram introduction. Journal of Animal Science, 70: 11951200.

Das, G. K., Naqvi, S. M. K., Gulyani, R., Pareek, S. R., Mittal, J. P. 1999. Effect of p4 and PMSG treatments on estrus response and fertility in acycling sheep during summer. Indian journal of animal sciences, 69(3): $178-179$.

Das, G. K., Naqvi, S. M. K., Gulyani, R., Pareek, S. R., Narula, H. K., Mittal, J. P. 2004. Estrus induction and fertility response in acycling Awassi-Malpura ewes treated with progesterone and PMSG in tropical climate. Indian journal of animal sciences, 74(7): 713-717.

Dogan, I., Nur, Z. 2006. Different estrous induction methods during the nonbreeding season in Kivircik ewes. Vet Med Czech, 51(4): 133-138.

Ekiz, E. E. and Ozcan, M. 2006. Sexual behavior and hormone levels of Kivircik ewes after estrus synchronization during and out of the breeding season. Arch. Tierz., Dummerstorf, 49(6): 583-592.

Epstein H. 1985. Biology of reproduction, suckling regimes, growth, and development. In: The Awassi sheep with special reference to the improved dairy type. Rome: FAO, 81-140.

Fitch, G. Q. et al., 1986. Sheep Industry Development Res. Digest, Fall. SAS. 1985. SAS User's Guide: Statistics (Version 5 Ed.). SAS Inst. Inc., Cary, NC.

Gardon, Juan. Carlos., Escribano, Begoña., Astiz, Susana., Ruiz, Salvador. 2015. Synchronization protocols in Spanish Merino sheep: reduction in time to estrus by the addition of eCG to a progesteronebased estrus synchronization protocol. Ann. Anim. Sci, 15(2): 409-418.

Garoussi, M. T., Farzaneh, Nima., Gallehdar, Ehsan., Mohri, Mehrdad. 2012. Reproductive performance in out of breeding season of fatty ewes using implant norgestomet with or without PMSG. Tropical Animal Health and Production, (ISI), 44(5): 965-968.

Haresign, W., 1978. Ovulation control in the sheep. In: Control of ovulation. Edited by. Crighton, D.B., Haynes, N.B., Foxcroft, G.R. and Lamming, G.E. Butterworths, London-Boston.

Hunter, R.H.F. 1980. Physiology and technology of reproduction in female domestic animals. Academic Press Inc. (London) Ltd.

Husein, Mustafa Q. and Kridli, Rami T. 2002. Reproductive Responses of Awassi ewes treated with either naturally occurring progesterone or synthetic progestagen. Asian-Aust. J. Anim. Sci, 15(9): 12571262.

Iida, K., Kobayashi, N., Kohno, H., Miyamoto, A., Fukui, Y. 2004. A comparative study of induction of estrus and ovulation by three different intravaginal devices in ewes during the nonbreeding season. $J$ Reprod Dev, 50(1): 63-69.

Jarquin, S., Roldan A., Zarco, L., Berruecos, J., Valencia, J. 2014. Effect of stage of the 
estrous cycle at the time of initial exposure to rams on the ovarian activity of Pelibuey ewes. Czech J. Anim. Sci, 59(11): 504-510.

Jordan, K. M. 2005. Approaches to improve the ovulatory response and reproductive performance of ewes introduced to rams during seasonal anestrus. West Virginia: West Virginia University. 90.

Juma, F.T. 2010. Effect of Prostaglandin and PMSG on prolificacy and some serum biochemical changes of Hamdani ewes synchronised with intravaginal progestagen. Al-Anbar Journal of Veterinary Science, 3(2): ISSN 19996527.

Kashifalkitaa, H. F. 2003. A study of the effect of deep freezing with comparisons between AI and natural mating and hormone treatment on the conception rate of black Iraqi goats. Baghdad UniversityColl. Vet. Med. Dept. Obst. Surg.

Kohno, hirohide., Okamoto, chika., Iida, kenji., Takeda, tomoko., Kaneko, etsushi., Kawashima, chiho., Miyamoto, akio., Fukui, yutaka. 2005. Comparison of estrus induction and subsequent fertility with two different intravaginal devices in ewes during non breeding season. Journal of reproduction and development, 51(6): 805-812.

Kor, Nasroallah. Moradi., Sadeghi, Somayeh., Ziaei, Nemat. 2012. Comparison reproductive performance in Kermani ewes treated with two synchronization methods and subsequent eCG treatment out of the breeding season. Int J Biol Med Res, 3(2): 1485-1489.

Kusina, N. T., Tarwirei, F., Hamudikuwanda, H., Agumba, G. and Mukwena, J. 2000. A comparison of the effects of progesterone sponges and ear implants, pgf2alpha, and their combination on efficacy of estrus synchronization and fertility of mashona goat does. Theriogenology, 53: 15671580 .

Marco-Jimenez, Francisco., Vicentel, Jose Salvador., Viudes-de-Castro, Maria Pilar. 2014. Effects of long-term fluorogestone acetate treatment combined with PMSG on oestrus synchronization and fertility in Guirra Ewes. Journal of Animal and Veterinary Science, 1(4): 25-29.

Mcleod, B. J. and Haresign, W. 1984. Induction of fertile estrus in seasonaly anestrus ewes with low doses of GnRH. Animal Reproduction Science, 7: 413-420.

Mellado, M., Olivas, R. and Ruiz, F. 2000. Effect of buck stimulus on mature and prepubertal norgestomet-treated goats. Small Ruminant Research, 36: 269-274.

Oldham, C. M., Boyes, T. and Lindsay, D. R. 1984. Can the "ram effect" plus PMSG be usedto advance the breeding season of Southdown ewes? Proceedings of the Australian Society of Animal Production, 15: 505-508.

Omontese, Bobwealth. Oakina., Rekwot, Peter. Ibrahim., Makun, Hussaina. Joan., Ate, Iyorhemba. Utim., Rwuaan, Joseph. Sankey. 2012. induction of estrus in Sahel goats using Fluorogestone Acetate (FGA) sponges and equine chorionic gonadotrophin (ECG). Skoto j. vet sci, 10(2): 21-25.

Perkins, A. and Fitzgerald, J. A. 1994. The behavioral component of the ram effect: The influence of ram sexual behaviour on the induction of estrus in an ovulatory ewes. Journal of Animal Science, 72: 5155.

Redmer, D. A., Kirsch, J. D., Kraft, K. C., Limesand, W., Grazul-Bilska, A. T. And Reynolds, L. P. 1998. Use of a synthetic progestogen in combination with a superovulatory treatment for induction of synchronized estrus in seasonally anovular ewes. NDSU Main Experiment Station, Fargo.

Robinson, T. J. 1967. Conclusions in: The control of the ovarian cycle in sheep. Edited by Robinson, T.J. Sydney University press.

Romano, J. E. 1993. Effect of service on estrus duration in dairy goats. Theriogenology, 40: 77-84.

Romano, J. E. 1994a. Effects of service number on estrus duration in dairy goats. 
Theriogenology, 41: 1273-1277.

Romano, J. E. 1994b. Effects of different stimuli of service on estrus duration in dairy goats. Theriogenology, 42: 875879.

Rosa H. J. D. and Bryant, M. J. 2003. Seasonality of reproduction in sheep. Small Ruminant Research, 48: 155-171.

Santos, G.M.G., Silva-Santos, K.C., MeloSterza, F.A., Mizubuti, I.Y., Moreira, F.B., Seneda, M.M. 2011. Reproductive performance of ewes treated with an estrus induction/synchronization protocol during the spring season. Animal Reproduction, 8(1/2): 3-8.

Sareminejad, P., Tabatabaei, S., Mamouei, M., Mirzadeh, K. And Boujarpour, M. 2014. The effects of short and long term Medroxy Progesterone Acetate (MAP) sponge treatments on reproductive performance during the non- breeding season of Arabian ewes. Iranian Journal of Applied Animal Science, 4(4): 747-751.

Taher, Jawad. K. 2014. Different estrus induction methods in Awassi ewes during the out of breeding season. Bas.J.Vet.Res, $1(2)$.

Tritschler II, J. P., Duby, R. T., Parsons, E. M., Parson, M. J. and Giordano, D. J. 1991. comparison of two progestogens during out-of-season breeding in a commercial ewe flock. Theriogenology, 35(5): 943.

Ungerfeld, R., Carbajal, B., Rubianes, E. and Forsberg, M. 2005. Endocrine and ovarian changes in response to the ram effect in MAP-primed Corriedale ewes during the breeding and non-breeding season. Acta Veterinaria Scandinavica, 46: 33-44.

Ustuner, B., Gunay, U., Nur, Z. and Ustuner, H. 2007. Effect of long and short-term progestagen treatments combined with PMSG on oestrus synchronization and fertility in Awassi ewes during the breeding season. Acta. Vet. Brno, 76: 391397.

Van Niekerk, C. H. and Belonje, P. C. 1970. The time of ovulation after the synchronisation of oestrus in Merino ewes with medroxy-progesterone acetate. Proc. S. Afr.Soc. Anim. Prod, 9: 177.

Walkden-Brown, S. W., Martin, G. B. and Restall, B. J. 1999. Role of male-female interaction in regulating reproduction in sheep and goats. Journal of Reproduction and Fertility Supplement, 52: 243-257.

Wildeus, S. 2000. Current concepts in synchronization of estrus: Sheep and goats. Journal of Animal Science, 77: 114.

Yelich, J. V. et al., 1992. Okla. Agr. Exp. Sta. Res. Rep, MP-, 136: 413.

Zonturlu, Abuzer Kafar., Özyurtlu, Nihat, Kaçar, Cihan. 2011. Effect of different doses PMSG on estrus synchronization and fertility in Awassi ewes synchronized with progesterone during the transition period. Kafkas Univ Vet Fak Derg, 17(1): 125-129.

\section{How to cite this article:}

Jaan Mohammad Wani, Utsav Sharma, Sajad A. Beig, Suhaib ul Haq Khan, Moien Javaid, Mudasir Bashir, A.K. Pandey, Umer Ali and Rouf Rashid Dar. 2017. Studies on Estrus Induction in Ewes during Non-Breeding Season. Int.J.Curr.Microbiol.App.Sci. 6(12): 11071115. doi: https://doi.org/10.20546/ijcmas.2017.612.125 